\title{
Life stories of depressed adult women in peri-urban Namibia
}

\author{
NN Shifiona, M Cur \\ School of Nursing, University of Johannesburg \\ M Poggenpoel, M, RN, PhD. \\ Professor: School of Nursing, University of Johannesburg \\ CPH Myburgh, HED, BSc Hons, M Com, DEd. \\ Professor: Department of Educational Psychology, University of Johannesburg
}

\section{Keywords:}

Depression, guidelines for psychiatric nurses

\section{Correspondence address:}

Prof M Poggengoel

School of Nursing

University of Johannesburg

PO Box 524

AUCKLAND PARK

2006

Tel : (011) 489-2860

Fax : (011) 489-2257

E-mail : mpo@edcur.rau.ac.za

\section{Abstract: Curationis 29(2): 5-11}

The problems women in peri-urban Namibia are faced with are multi-dimensional. Like women in other communities they face the pressure of having a number of responsibilities, namely working, being a wife and mother, taking care of their families and perhaps caring for aging parents. Sometimes the pressure can be too overwhelming to manage. As a result, many women become depressed. Studies on depression among black African women in Namibia could not be traced. It was therefore considered to find out how women suffering from depression from this part of the world tell their life stories.

The purpose of the study was two-fold: Firstly, to explore and describe the life stories of depressed adult women in peri-urban Namibia, and secondly to use the information obtained to describe guidelines for psychiatric nurses working with these patients at psychiatric outpatient clinics as well as in the community.

A qualitative phenomenological research design of an explorative, descriptive and contextual nature was used. The researcher approached the subjects and their experiences with an open mind. Ten depressed adult women between 21-55 years were involved in the research. The researcher strived to adhere to the principles of trustworthiness. To ensure this Guba's model (in Krefting, 1991: 217) of trustworthiness was adopted. All the interviews were analysed following Tesch's method (Creswell, 1994: 154-55). The services of an independent coder were obtained.

The results indicated that impaired interpersonal interactions and stressful life events have a negative influence on the daily life of women leading to the development of depressive symptoms. Guidelines to support psychiatric nurses working with depressed women were drawn up.

\section{Opsomming}

Die probleme waarmee vroue in buitestedelike Namibië gekonfronteer word is multidimensioneel. Soos vroue in ander gemeenskappe ervaar hulle die druk van baie verantwoordelikhede soos ' $n$ werk, om 'n vrou en moeder te wees, om vir hulle gesinne te sorg en om moontlik vir bejaarde ouers te sorg. Somtyds kan die druk te oorweldigend wees om te hanteer. Dit het tot gevolg dat die vroue depressief word. Studies oor depressie by swart vroue in Namibië kon nie opgespoor word nie. Die navorser het dus besluit om uit te vind hoe vroue van hierdie deel van die wêreld wat aan depressie ly hulle lewensverhale vertel. 
Die doel van hierdie studie was tweeledig: Eerstens om die lewensverhale van depressiewe volwasse vroue in buitestedelike gebiede in Namibië te verken en te beskryf en tweedens om die inligting wat verkry is te gebruik om riglyne te beskryf vir psigiatriese verpleegkundiges wat met hierdie pasiënte werk by klinieke vir psigiatriese buitepasiënte asook in die gemeenskap.

'n Kwalitatiewe fenomenologiese navorsingsontwerp van ' $n$ verkennende, beskrywende en kontekstuele aard is beskryf. Die navorser het die deelnemers en hulle belewenisse met 'n oop gemoed benader. Tien depressiewe volwasse vroue tussen 21-55 jaar was by hierdie navorsing betrokke. Die navorser het gepoog om aan die beginsels van vertrouenswaardigheid te voldoen. Guba se model (in Krefting, 1991: 217) vir vertrouenswaardigheid is dus gebruik. Al die onderhoude is deur middel van Tesch se metode (Creswell, 1994: 154-55) geanaliseer. Die dienste van ' $n$ onafhanklike kodeerder is verkry.

Die resultate het aangedui dat swak interpersoonlike interaksies en stresvolle lewensgebeurlikhede 'n negatiewe invloed het op die daaglikse lewe van vroue en dat dit daartoe lei dat simptome van depressie ontwikkel word. Riglyne is daargestel om psigiatriese verpleegkundiges te help om depressiewe vroue te ondersteun.

\section{Introduction}

During 1996 (January-December) a total of 403 female psychiatric patients were admitted to Oshakati Hospital Psychiatric Unit in Namibia (Female Admissions' Register, Oshakati Psychiatric Unit, 19961997). Health workers at this unit reported that the problem was more common among females between 21 and 55 years of age. During the same period a high suicide rate was common in this population although the latter affected both males and females. Depression was often reported being the outstanding clinical manifestation among patients with suicidal tendencies. Community members expressed their concern about the suicide rates. Little was being done locally to elicit answers to their questions regarding the disorder.

The state of mental health problems in the region was characterised by inadequate mental health facilities, insufficient mental health personnel like psychiatrists, psychiatric nurses, social workers and clinical psychologists, as well as a lack of interest and a negative attitude towards mental illness among some of the health personnel.

The focus of this study was on depressed adult women between 21-55 years. This age group was chosen because of a number of major life changes taking place during this period. Some of these major changes include: experience of a major cri sis related to marital problems, job changes, assumptions of major social roles and the evolution of an adult self during early and middle adulthood. During middle adulthood important gender changes occur. As the women approach the age of 50 , they clearly define what they want from their work, family and leisure. However, sometimes a lack of freedom in life-style, rigidly established social rules and a sense of entrapment may lead to depression and a loss of confidence.

The following questions arose:

- What are the life stories of depressed adult women?

- How do they write and rewrite the stories of their life?

- How can the obtained information be utilised to describe guidelines to develop a mental health education program to support these women?

The purpose of this study was twofold:

- Exploration and description of the life stories of depressed adult women.

- Description of guidelines for the compilation of a mental health education support program for psychiatric nurses to assist depressed adult women in mobilising their resources to facilitate the promotion, maintenance and restoration of their mental health as an integral part of health.

\section{Research design and method \\ Research design}

A qualitative, ex plorative, descriptive and contextual research design (Mouton \& Marais, 1989: 45; Mouton, 1996: 103-169) was utilised to conduct this research. The aim was to explore the life stories of adult depressed women that would enhance the understanding of how these women tell their life stories. This understanding formed the basis of the description of guidelines to develop a mental health education program to support these women.

\section{Research method}

This research was conducted in two phases:

Phase One: The exploration and description of the patterns in the life stories of depressed adult women. A nonprobability, purposive, convenient method was used to select ten participants (Creswell, 1994:15). Data gathering included in-depth phenomenological audiotaped interviews, field notes and the use of communication techniques (Kvale, 1983: 171-196; Omery, 1983: 49-63). The interviews focused on the life stories of the specific participants. One central question was posed namely: "Tell me your life story". The interviewer created a context were the participants could speak freely and openly by utilising communication techniques such as clarifying, probing, paraphrasing, summarising, reflecting as well as minimal response. During the interviews the interviewer used bracketing (putting preconceived ideas aside and intuiting (focusing on the life stories of the participants regarding depression). Interviews were conducted until the data were saturated as demonstrated by repeating themes. The interviewer wrote field notes based on observations during the interviews. Data were analysed using Tesch's descriptive method (Creswell, 1994: 154-155).

After a consensus discussion between the independent coder and the researcher, the identified themes were presented. A literature control was done to verify the results.

Phase Two: Guidelines were drawn up to develop a mental health education support program for psychiatric nurses to assist depressed adult women in mobilising their resources to facilitate the promotion, maintenance and restoration of their mental health as an integral part of health.

The data collected from participants were used as a basis for describing the guidelines. A literature control was done 
and the guidelines were discussed with psychiatric nurses to ascertain the practical applicability thereof in practice.

\section{Measures to ensure trustworthiness}

Measures to ensure trustworthiness were taken. Guba's (Lincoln \& Guba, 1985: 290327) strategy of credibility, transferability, dependability and confirmability was applied. Activities in achieving credibility were prolonged and varied field experience, time sampling, reflexivity, member checking, peer examination, interview technique, establishing the authority of the researcher and structural coherence were employed. Transferability was obtained by using a purposeful sample working contextually and using dense descriptions. Dependability was achieved by doing a dependability audit, providing a dense description of research methods (data gathering, data analysis and interpretation). Confirmability was achieved by ensuring an audit of the entire research process, reflexive analysis and triangulation.

\section{Ethical measures}

Ethical measures were adhered to during the research process. These include informed consent of participants ensuring confidentiality and anonymity and competence of the researcher and the researcher-interviewee relationship (South African Nursing Association, 1998:5).

\section{Results}

The two major themes as well as categories and sub-categories were identified from the life stories as verbalised by the participants:

\section{Impaired interpersonal interactions}

Poor interpersonal relationships related to impaired communication as evidenced by the following relationships:

$$
\begin{aligned}
& \text { Marital } \\
& \text { Partnerships } \\
& \text { Family, friends and others. }
\end{aligned}
$$

\section{Stressful life events}

Lack of personal worth related to disempowerment as evidenced by:

Deprivation of personal

freedom

Inability to bear children

Inadequate emotional, financial and material support

Emotional, spiritual and physical distress

Loosing control.

These themes will now be discussed and supported by direct quotes from the depressed women and the literature control (Shifiona, 1998:39-67).

\section{Impaired interpersonal interaction}

Impaired interpersonal interaction made the daily lifestyle of depressed women difficult and at times intolerable. These women suffered varying degrees of impaired feelings in their daily lives, including unhappiness, withdrawal, loneliness, uselessness, hopelessness, emotional pain, anger and frustration (Moreau, 2004: 187-190).

\section{Poor interpersonal relationships related to impaired communication with a spouse}

Participants indicated severe relationship problems experienced during married life. Impaired communication had been observed as a stumbling block between them and their spouses. This is evident from the following statements:

"...my own husband is the source of my problems, we don't understand each other at all ...".

Another participant experienced it as follows: "When I came back home I found another woman in the house. What came to my mind was that probably she is visiting because I did not know her. To my greatest shock and disappointment I was told that she will be a second wife whether I like it or not".

Heifner (1996:5) describes women's depression in relation to ordinary, daily life issues like the burdens of marriage and child rearing which falls much more heavily on women. This type of relationship contributes to women becoming more submissive to a dominant other, especially the spouse, leading to increased feelings of helplessness and hopelessness. In the absence of a positive or more promising relationship between two partners, it becomes very difficult for spouses, families and friends to understand depression and to realise its impact on an individual.

In another study on abusive relationships Weingourt (1996:16) concludes that women assume full responsibility for the caring in relationships, often attending to the needs of others at their own expense. In unequal domestic relationships, the women's attempts to grow, succeed and excel are perceived by the man as an attempt to demean him, and ultimately leave him. In order to protect and nurture the man she loves, the woman must ignore, deny and even acts against her own needs. This eventually results in anger and frustration which is again suppressed by the particular woman (Weingourt, 1996: 17). Suppression will therefore lead to feelings of helplessness, weakness, unworthiness and inferiority. One participant expressed it as follows: “... when I am angry, I don't talk at all, I go to my room and lock myself inside".

Weingourt (1996: 17-18) further emphasises that poor interpersonal relationships negate the woman's experience. She will try to make herself acceptable by denying and redefining large parts of her experiences as bad, wrong and unacceptable. In the end she looses feelings of self-worth, she feels powerless, experiences a distorted sense of self and a diminution of her ability to understand others.

At this point. loneliness, isolation and fear of abandonment dominate. One participant complained: "I was chased out of the house, I felt abandoned. Where will I go with my baby?" In the depth of suffering, people may perceive themselves as abandoned and forsaken by everyone. That which gave life its meaning has become empty and void.

\section{Poor interpersonal relationships related to impaired communication with a partner}

Participants expressed how their relationships were severely affected by unhealthy communication patterns. This is evidenced by the following excerpts from the transcripts:

"I felt said most of the time when looking at the situation I found myself in, and all the unfulfilled promises, I felt abandoned".

"He n'as very unfaithful and cruel, had several girlfriends, it was very painful, you are all alone".

Another participant described the relationship as disappointing: "... he dissociate himself from us, was not just there, I was very unhappy, frustration and anger were my main problems...".

Obviously all these women were alone in 
their fragile relationships. Any strain in this kind of relationship may result in inability to care for a person's physical and emotional needs resulting in stress. Feelings of neglect, hurt, bitterness and unfairness were common among these women. Prolonged disruptive relationships lead to anxiety, and if it remains unsolved, it will eventually result in depressive episodes.

Poor interpersonal relationships related to impaired communication with the family, friends and others

Some participants attributed their problems to a poor understanding of their condition by the people whom they live with. The latter is supported by the following extract: “... my brothers-andsisters-in-law kept on gossiping about me, laughing and swearing at me ... “.

One participant's parents refused to offer support to further her studies, because they believed that paying her school fees will be a waste of money. As this participant put it: "... fees will not be paid, because I will not manage at school, being mad ...." The participant felt demoralised by her parents' negative attitude. Her uniqueness and capabilities were not considered at all. This made her feel small and worthless with a low selfesteem. Warren (1997:109) explains it further by saying that persons with low self-esteem view themselves as deficient and inadequate, although it is unclear if low self-esteem is a causal factor or a symptom of depression. It should be noted that in relationships that are disintegrating, there is usually a mounting level of anxiety that is shared by the person and significant others family members, friends and others (Beeber, 1996: 154-155).

As interpersonal relationships are regarded as connections between people, its absence leads to poor interpersonal relations as experienced by almost all the women in this study.

\section{Stressful life events}

All the participants have gone through one or more stressful life event. Warren (1997: 109) describes how continued bombardment of stress may alter a woman's cognitive appraisal ability so that she view each life event as being harmful or threatening and not a challenge she can manage. Categories discussed here are:

Lack of personal worth related to disempowerment as evidenced in the deprivation of personal freedom

Powerlessness, a universal symptom experienced by depressed women, is related to the disruption of the selfsystem and -control in the face of external or internal stressors.

Loss of personal power is usually a precursor to feelings of hopelessness, helplessness and despair experienced by a depressed woman. Some women felt that being sick had evoked in them feelings of being stripped of their own dignity, autonomy and personal worth. One woman described it as follows: "Lining up for food and medications was an extremely humiliating and painful experience for me".

Another participant commented on the labelling process: “... mad/crazy people ...".

The participants felt that this attitude was humiliating and deprived them from their personal freedom and value as individuals. They believed their personal worth was not respected at all.

Lack of personal worth related to disempowerment as evidenced in the inability to bear children

One participant revealed how she was suffering the humiliation because of inferiority.

" I could unfortunately not bear my own children, culturally as soon as you fail to fall pregnant, then you are nothing ... I live under pressure from my husband, in-laws and neighbours. $M y$ husband has now extra-marital affairs and I am not allowed to utter a word on his behaviour".

Another woman stated: " I'm told without a child I'm nothing". This is supported in the literature. Atwood and Dobkin (1992:389) state that the major emotional toll is a deep sense of loss. Some women related the loss of self-esteem and personal worth to failure in becoming pregnant. The participant further stated that the future looked bleak and she saw no reason to continue with such a relationship or to be alive.

Lack of personal worth as related to disempowerment as evidenced in inadequate emotional, financial and material support

The absence of emotional as well as financial support was raised by most participants during the interview.

One woman said: “. . . he was not just there for us, we needed his support so much...".

Another woman said: "I struggle alone with my child, but I did not have courage to report him for support...".

These women were simultaneously burdened by suffering and time constrained by the activities of their daily lives. The resources to support them were curtailed or non-existent. Absence of support had led to an insecure lifestyle as most of them expressed uncertainty about their own personal worth and future.

Lack of personal worth as related to disempowerment as evidenced in emotional, spiritual and physical distress

Participants reported a variety of emotional and spiritual experiences as they went through depressive episodes. They lived their lives with a sense of dissatisfaction, little understanding and a degree of chronic unhappiness. One woman expressed it as follows: “... I did not know' what was wrong with me, my relatives told me that I'm sick, uuh! I felt bad, you know!"

Depressed women share a sense of being incomplete and unintegrated as though something of them was missing. They live in conflicting relationships and are in conflict with themselves as they try to live out the expectations they perceive others have of them. One woman described it as follows: "Our relationship was heartbreaking, was marked by unhappiness everyday, but because I love this man, I did not want to leave him." This is supported in literature by Schreiber (1996:166) that the women's decisions were based on a narrow understanding of their lives and their relationships. The following feelings were common:

\section{o bitterness and blame}

They blamed themselves about their inability to fall pregnant and their inability to bring about changes within the relationship from a negative to a positive and acceptable one.

\section{o sadness and hurt}

One woman said: "I felt hurt and very angry. I was betrayed and being used by this man".

\section{o defeat and helplessness}

One participant said: "I tried to confront him about his behaviour, but he does 
not want to listen to me, instead he beats me up severely".

\section{anxiety and worry}

Depressed women experience anxiety about their condition as well as what the future held for them. One woman stated: "Now I am sick, I am not employed, the support I am getting is not sufficient, my future looks dark...".

\section{o shame and being stigmatised}

Depressed women feel ashamed about themselves and the stigma attached to them as individuals. One woman explained it as follows: "I did not want my colleagues to know that I am depressed". According to Younger (1995:61) an experience of shame is isolating, highly personal and results in feelings of loss of control, inferiority, abandonment and rejection. What is exposed in shame is oneself, namely "I am ashamed of what I am".

Participants were also complaining about a number of physical distress symptoms such as dizziness, loss of appetite, headache and lack of energy. These symptoms were a reflection of the condition they were suffering from.

Lack of personal worth as related to disempowerment as evidenced in loosing control

A woman in this phase of her depressive experience is in a crisis situation, confronting her depression. Many of them spoke about being in a "dark cloud". One woman said: "I have been covered by dark shadow, I did not know where I was and one day I decided to hang myself because my future was just dark". At this stage the woman may feel that she has got no future. It is a terrifying experience for the woman and the fear she experiences when thinking about these heavy clouds leaves her in despair and apprehension.

Jambunathan (1996:28) concludes that depressed women at this stage have no confidence, no feelings of self-esteem, pride or personal worth. This is the time when they develop suicidal thoughts. According to Moreau (2004:187) nearly " $15 \%$ of patients with untreated depression commit suicide". Guidelines for psychiatric nurses assisting depressed women are thus a necessity.

\section{Guidelines for psychiatric nurses}

The guidelines are based on the themes identified from the phenomenological interviews and observations of depressed adult women. Impaired interaction and stressful life events which are experienced by depressed women, form the basis of these guidelines.

The following guidelines are suggested for use by psychiatric nurses in assisting depressed women in their quest for mental health and wholeness.

The appropriate strategy for improving the situation is for psychiatric nurses to make use of the psycho-educational approach when addressing the problem. The term "psycho-education" refers to the training of individuals in psychological knowledge or skills, therefore a psycho-educational program will be useful to depressed women.

According to Maynard (1993:9) a psycho-educational group program provides a more comprehensive intervention framework for women who are depressed. The emphasis is placed on addressing issues such as changing cognitive patterns, improving interpersonal communication as well as increasing self-esteem. Knowledge and skills are taught through this program that can prevent depressive symptoms from becoming severe enough to require hospitalisation. For those who have been in hospital the group provides outpatient support and assistance to help prevent or reduce recidivism. In the psychoeducational model, providing information and skills training are the major helping functions. The aim is to assist depressed women towards autonomous functions.

\section{Framework of a psycho- educational program}

This program includes the following: group format; psychiatric nurse and psycho-education groups and psychoeducational content.

\section{- Group format}

The group format entails a small group consisting of eight to ten depressed women. This group will allow discussion of issues such as anger, abandonment, rejection and dependency as experienced within relationships. The group provides positive identification with other women, increased realistic self-assessment and feelings of empowerment, and ultimately improved heterogeneous relationships. Within the group, depressed women provide feedback to each other leading to a built-in support system.

\section{- $\quad$ Psychiatric nurse and psycho-educational groups}

The objectives of the group includes the following:

to emphasise the importance of social factors in the development of depression; to supply information related to the development and symptoms of depression; to help depressed women identify self-defeating thoughts and replace them with positive ones;

to help women develop assertiveness and coping skills; and

to teach methods to increase self-esteem in depressed women.

\section{- Psycho-educational content (see figure 1)}

Participation by depressed women in this intervention strategy will therefore improve feelings of security, self-reliance, self-esteem, independence and selfrespect. Psychiatric nurses should make themselves available after the termination of the last session should the group require further discussions on an individual basis. Group members can share conflict management, stress management and assertive skills with the psychiatric nurse, which will ultimately help them deal with difficulties in their relationships.

\section{- $\quad$ Provide strategies to deal with stressful life events}

The focus should be on empowering depressed women to maintain patterns that would support growth and to change patterns that would create problems in their daily lives. Empowerment will enable depressed women to make choices in their lives. Women should be assisted to establish support groups which will provide a venue for them to explore their feelings and to learn what others consider as normal. Patient education brochures on various topics related to depression should be made available to them. Psychiatric nurses should assist women in building confidence through counselling on an individual or group basis.

Financial and material distress could be 


\begin{tabular}{|c|c|c|}
\hline Meeting No. & Topic & Content \\
\hline 1 & Depression & $\begin{array}{l}\text { Give information about depression (for example, the } \\
\text { nature of depression, symptoms of depression, causes of } \\
\text { depression and social factors related to depression in women. }\end{array}$ \\
\hline 2 & $\begin{array}{l}\text { Role of social factors in } \\
\text { depression }\end{array}$ & $\begin{array}{l}\text { Identify factors in society oppressive to women and how } \\
\text { their lives are affected. } \\
\text { Identify factors that could be changed. } \\
\text { Discuss marital and parenting relationships. } \\
\text { Discuss how current social expectations of women } \\
\text { influence feelings. } \\
\text { Discuss women's multiple roles and the effect thereof } \\
\text { on their relationships. }\end{array}$ \\
\hline 3 & Goal setting & $\begin{array}{l}\text { - } \quad \text { Discuss types of goals to be met by them. } \\
\text { - } \quad \text { Share goal setting with the group. }\end{array}$ \\
\hline 4 & Self-esteem & $\begin{array}{l}\text { Discuss issues related to self-esteem. } \\
\text { - } \quad \text { Share techniques for improving self-esteem. }\end{array}$ \\
\hline 5 & Assertiveness & $\begin{array}{l}\text { Share information about characteristics of assertive } \\
\text { behaviour. } \\
\text { Discuss and practice skills for accepting and giving } \\
\text { criticism, communicating needs and saying no. }\end{array}$ \\
\hline 6 & Stress management & $\begin{array}{l}\text { Provide information about stress and its role in } \\
\text { depression. } \\
\text { Discuss physiological and psychological responses to } \\
\text { stress. } \\
\text { Teach stress management strategies. }\end{array}$ \\
\hline 7 & Review and terminate & $\begin{array}{l}\text { - Share positive feelings and experiences from the group } \\
\text { meetings. } \\
\text { Discuss what they have gained from meetings. }\end{array}$ \\
\hline
\end{tabular}

reduced if psychiatric nurses use their interactive and facilitative skills to work with organisations, professional and non-professional groups and assert their efforts in lobbying for upgrading community infrastructures. Women should be encouraged to start income generating projects so as to eliminate the dependence syndrome. Family support and education, family therapy and couple counselling can help depressed women and families address interpersonal conflicts.

\section{Conclusions, limitations and recommendations}

In conclusion the study revealed factors within women's daily lives which were regarded as core to the main problems.
These predisposing factors include, among others, unfaithful partners, poor understanding of the woman's condition, disappointing relationships, unsympathetic family members, neighbours and friends as well as disconnected family relationships. High demands are imposed on the women with little recognition.

It is therefore incumbent upon the psychiatric nurse to beware of the presence of the negative factors and its impact on the mental health of women and to assist women in mobilising their resources in promoting, maintaining and restoring their mental health as an integral part of health. The guidelines suggested here are intended to empower psychiatric nurses and others who come into contact with this target group, with the necessary knowledge and skills.

Limitations of this study include that interviews could not be conducted in participants' homes as planned because of transport problems and long distances between the clinic and participants' homes. Member checking with all the participants was also impossible because all of them could not be reached because of the problem stated above. With the exception of two interviews, all other interviews were conducted in the vernacular (Oshiwambo). Since this study was conducted in the vernacular it was necessary to translate the data into English. This translation might have resulted in loosing or distorting the originality of the participants' everyday lives as expressed in the original 
language, therefore only the main themes, categories and subcategories were translated.

Recommendations are made with specific reference to psychiatric nursing practice, psychiatric nursing education and further nursing research.

\section{- $\quad$ Psychiatric nursing practice}

It is clear from the research results that depressed adult women require professional help and support in dealing with their experiences of depression. Psychiatric nurses should be involved in counselling sessions to assist depressed women. Community resources such as churches need to be mobilised so that they could offer assistance through counselling depressed women.

\section{- $\quad$ Psychiatric nursing education}

The guidelines generated from the findings can be considered in designing in-service education programs for all health workers and curricula for the training of psychiatric nurses at underand post-graduate level.

\section{- $\quad$ Psychiatric nursing research}

The results of the research conducted should be disseminated to all psychiatric nurses. Further research need to be conducted to assess whether the guidelines provided in this study were effective in improving the patterns of interactions between the internal and external environment of depressed women.

\section{References}

ATWOOD, JD \& DOBKIN, S 1992: Storm clouds are coming: ways to help couples reconstruct the crisis of infertility. Contemporary Family Therapy. 14(5), October 1992: 385-403.

BEEBER, LD 1996: Pattern integration in young depressed women: Part 1 . Archives of Psychiatric Nursing. 10(3), June 1996: 151-156.

CRESWELL, JW 1994: Research design: Qualitative and quantitative approaches. London: Sage.
1997: Northwest Health and Social Services Directorate: Annual Report, 1996/1997:2.

HEIFNER, CA 1996: Women, depression and biological psychiatry: Implications for psychiatric nursing. Perspectives in Psvchiatric Care. 32(3), July-September, 1996: 5-9.

JAMBUNATHAN, J 1996: Depression: Dealing with the darkness. Perspectives in Psychiatric Care, 32(1), January-March 1996: 27-29.

KREFIING,L 1991: Rigor in qualitative research: the assessment of trustworhiness. American Journal of Occupational Therapy. 45 (3) : 214-222.

KVALE, S 1983: Qualitative research interviews. A phenomenological and hermeneutical mode of understanding. Journal of Phenomenological Psychology. 14: 171-196.

LINCOLIN, YS \& GUBA, EG 1985: Naturalistic inquiry. Beverly Hills: Sage.

MAYNARD, C 1993: Psychoeducational approach to depression in women. Journal of Psvchosocial Nursing. 31(12:9-14).

MOREAU, D (Ed.) 2004. Psychiatric nursing made incredibly easy. Philadelphia: Lippincott, Williams \& Wilkens.

MOUTON, J 1996: Understanding social research. Pretoria: Van Schaik.

MOUTON, J \& MARAIS, H 1989: Concepts in the methodology of social sciences. Pretoria: Human Science Research Council.

OMERY, A 1983: Phenomenology: A method for nursing research. Advances in Nursing Science. 5(2): 49-63.

OSHAKATI PSYCHIATRIC UNITS. 1996-1997: Female admissions' register. Oshakati: Oshakati Psychiatric Units.

SCHREIBER, R 1996: Understanding and helping depressed women. Archives of Psychiatric Nursing. 19(3), June 1996: 165-175.

SHIFIONA, NN 1998: Life stories of adult depressed women in peri-urban Namibia. Unpublished M. Cur
Psychiatric Nursing mini-dissertation. Auckland Park. Rand Afrikaans University.

SOUTH AFRICAN NURSING ASSOCIATION. 1991: Ethical standards for nurse researchers. Pretoria: Position Paper, South African Nursing Association.

WARREN, BJ 1997: Depression, stressful life events, social support and self-esteem in middle class AfricanAmerican women. Archives of Psychiatric Nursing. 10(3), June 1997: 107-117.

WEINGOURT, R 1996: Connection and disconnection in abusive relationships. Perspectives in Psychiatric Care. 32(2) April-June, 1996: 15-19.

YOUNGER, JB 1995: The alienation of the sufferer. Advances in Nursing Science. 17(4): 53-71. 